\title{
Reactive Oxygen Species
} Generation-Scavenging and Signaling during Plant-Arbuscular Mycorrhizal and Piriformospora indica Interaction under Stress Condition

\author{
Manoj Nath ${ }^{1 *}$, Deepesh Bhatt ${ }^{2}$, Ram Prasad ${ }^{1}$, Sarvajeet S. Gill ${ }^{3}$, Naser A. Anjum ${ }^{4}$ and \\ Narendra Tuteja ${ }^{1 *}$ \\ ${ }^{1}$ Amity Institute of Microbial Technology, Amity University Uttar Pradesh, Noida, India, ${ }^{2}$ Department of Biotechnology, Shree \\ Ramkrishna Institute of Computer Education and Applied Sciences, Veer Narmad South Gujarat University, Surat, India, \\ ${ }^{3}$ Stress Physiology and Molecular Biology Laboratory, Centre for Biotechnology, Maharshi Dayanand University, Rohtak, \\ India, ${ }^{4}$ Centre for Environmental and Marine Studies and Department of Chemistry, University of Aveiro, Aveiro, Portugal
}

\section{OPEN ACCESS}

Edited by:

Mohamed Hijri,

Université de Montréal, Canada

Reviewed by:

Rodica Pena,

University of Göttingen, Germany

Hojka Kraigher,

Slovenian Forestry Institute, Slovenia

*Correspondence:

Manoj Nath

ntuteja@icgeb.res.in

Narendra Tuteja

ntuteja@icgeb.res.in

Specialty section:

This article was submitted to

Functional Plant Ecology,

a section of the journal

Frontiers in Plant Science

Received: 11 July 2016 Accepted: 06 October 2016 Published: 21 October 2016

Citation: Nath M, Bhatt D, Prasad R, Gill SS,

Anjum NA and Tuteja T (2016)

Reactive Oxygen Species Generation-Scavenging and Signaling during Plant-Arbuscular Mycorrhizal and Piriformospora indica Interaction under Stress Condition.

Front. Plant Sci. 7:1574. doi: 10.3389/fpls.2016.01574
A defined balance between the generation and scavenging of reactive oxygen species (ROS) is essential to utilize ROS as an adaptive defense response of plants under biotic and abiotic stress conditions. Moreover, ROS are not only a major determinant of stress response but also act as signaling molecule that regulates various cellular processes including plant-microbe interaction. In particular, rhizosphere constitutes the biologically dynamic zone for plant-microbe interactions which forms a mutual link leading to reciprocal signaling in both the partners. Among plant-microbe interactions, symbiotic associations of arbuscular mycorrhizal fungi (AMF) and arbuscular mycorrhizal-like fungus especially Piriformospora indica with plants are well known to improve plant growth by alleviating the stress-impacts and consequently enhance the plant fitness. AMF and $P$. indica colonization mainly enhances ROS-metabolism, maintains ROShomeostasis, and thereby averts higher ROS-level accrued inhibition in plant cellular processes and plant growth and survival under stressful environments. This article summarizes the major outcomes of the recent reports on the ROS-generation, scavenging and signaling in biotic-abiotic stressed plants with AMF and $P$. indica colonization. Overall, a detailed exploration of ROS-signature kinetics during plantAMF/P. indica interaction can help in designing innovative strategies for improving plant health and productivity under stress conditions.

Keywords: plant root, ROS-metabolism, ROS-signaling, stress, arbuscular mycorrhizal fungi

\section{INTRODUCTION}

Plant-microbe interactions cover a broad range of relationships between plant and microbial community in which either of the partners participate by imposing a beneficial, negative or neutral effect on its counterpart. Moreover, plant roots are continuously exposed to a large number of microbes present in the rhizosphere that influence plant life cycle and overall fitness 
(Sanders, 2011; Mine et al., 2014). Plant-microbe symbiotic interactions have been the focus of recent plant stress research, where the outcomes of these interactions were credibly evidenced to alleviate biotic and abiotic stress-impacts and consequently enhance the plant fitness (Goh et al., 2013; Schouteden et al., 2015; Doty, 2016). In the present scenario, a relatively small number of beneficial plant-microbe interactions are well characterized and utilized (Farrar et al., 2014). Microbial counterpart- arbuscular mycorrhizal fungi (AMF)-mediated stress tolerance and growth enhancements have been extensively reported in colonized host plants during symbiotic interaction studies (Muthukumar and Udaiyan, 2010; Porcel et al., 2012; Tahat and Sijam, 2012). Notably, a number of recent works have discussed the significance of Piriformospora indica, a arbuscular mycorrhizal-like fungi which is able to grow in pure culture and without the presence of the plant. $P$. indica, a multifunctional and versatile root endophytic fungus belongs to Sebacinales (order-Basidiomycota) and is involved in the improvement of growth, yield, and plant tolerance to major biotic and abiotic stresses (Sherameti et al., 2008; Vadassery et al., 2009a,b; Cruz et al., 2013; Jogawat et al., 2013; Prasad et al., 2013; Bakshi et al., 2014; Johnson et al., 2014; Gill et al., 2016; Trivedi et al., 2016). Both fungal counterparts viz., AMF and $P$. indica are capable of improving plant fitness via changing mainly the chemical plasticity through altering reactive oxygen species (ROS) generation-scavenging under biotic and abiotic stresses (Beneventi et al., 2013; Goh et al., 2013; Hashem et al., 2016; Mo et al., 2016). ROS can be both radical and non-radical forms and generated in normal metabolic processes e.g., as a result of electron transport chains in chloroplast and mitochondria. However, adverse conditions including abiotic and biotic stresses can significantly accelerate the generation of ROS at cellular level (Apel and Hirt, 2004; Gill and Tuteja, 2010; Rasool et al., 2013). Radical forms of ROS majorly include superoxide radicals $\left(\mathrm{O}_{2}^{\bullet-}\right)$, perhydroxy radical $\left(\mathrm{HO}_{2}^{\bullet}\right)$ and alkoxy radicals $(\mathrm{RO})$; whereas, hydrogen peroxide $\left(\mathrm{H}_{2} \mathrm{O}_{2}\right)$ and singlet oxygen $\left({ }^{1} \mathrm{O}_{2}\right)$ are included in nonradical molecular form. Compared with non-radicals, radical forms of ROS are more toxic due to their highly reactive nature (Gill and Tuteja, 2010; Sewelam et al., 2016). In plants, enzymatic and non-enzymatic systems are the two major components of ROS-scavenging system. The list of major enzymatic components includes superoxide dismutase (SOD), ascorbate peroxidase (APX), monodehydroascorbate reductase (MDHAR), guaiacol peroxidase (GPX), glutathione reductase (GR), peroxidase (POD), and catalase (CAT). Major antioxidant metabolites namely glutathione (GSH) and ascorbic acid (AsA) belong to the list of non-enzymatic component (Apel and Hirt, 2004; Gill and Tuteja, 2010; Rasool et al., 2013). Notably, NADPH oxidases and respiratory burst oxidase homologs are the key components of ROS generation system in plants (Suzuki et al., 2013; Kadota et al., 2015).

In order to alert the plants for stress-adaptation, initial generation of ROS was reported to act as long distance signals in response to stress (Mittler et al., 2011; Sewelam et al., 2016). Furthermore, ROS are also thought to be generated during early stages of symbiotic interactions of mycorrhizal fungi associated with plant roots (Fester and Hause, 2005; Tanaka et al., 2006; Puppo et al., 2013; Espinosa et al., 2014; Kiirika et al., 2014). Though, to efficiently utilize ROS as signaling molecule, plants must sustain a precise balance between ROS generation and ROS-scavenging pathways in order to finally mitigate the potential toxic effects of ROS (Mittler et al., 2004; Baxter et al., 2014). In plants, stress signals include redox homeostasis, antioxidants signaling and continuous production/scavenging of ROS at cellular level (Bose et al., 2014; Jajic et al., 2015). However, severity or prolonged duration of biotic and abiotic stresses can reduce the capability of plant to neutralize excess ROS production that alternatively cause oxidative stress and finally affect cellular essential metabolic activities and viability (Gill and Tuteja, 2010; Barna et al., 2012; Nath et al., 2016).

Despite the previous facts, literature is scanty on how the generation, signaling and metabolism of ROS can be modulated in plants with $\mathrm{AMF} / P$. indica association under stress conditions. Hence, this paper aims to briefly appraise ROS accumulation, homeostasis, and signaling during plant-AMF and $P$. indica interaction in response to major stress conditions.

\section{ROS GENERATION AND SCAVENGING DURING PLANT-ARBUSCULAR MYCORRHIZAL INTERACTION UNDER STRESS CONDITIONS}

Reactive oxygen species profiling in AMF-inoculated roots of several plants including Medicago truncatula, Zea mays, and Nicotiana tabacum has evidenced important role of mycorrhizal colonization/arbuscules in the scavenging of major ROS such as $\mathrm{H}_{2} \mathrm{O}_{2}$ (Fester and Hause, 2005). AMF-colonization improved drought tolerance in olive plants, where compared to noncolonized olive plants, AMF-colonized plants exhibited lesser accumulation of $\operatorname{ROS}\left(\mathrm{H}_{2} \mathrm{O}_{2}\right)$ and malondialdehyde (MDA), a lipid peroxidation product (Fouad et al., 2014). Similar results were also reported in other test plants including date palm (Benhiba et al., 2015) and Citrus reticulata (Sarkar et al., 2016), where improved drought tolerance was dedicated to AMF-mediated improvements in the antioxidant defense of host plants and alleviate drought stress-effects. A recent report also confirmed the role of AMF (Glomus versiforme) colonization in the enhancement of ROS-metabolism via its modulatory role in the activities of antioxidant enzymes including SOD, CAT, APX, GR, and MDHAR in drought stressed water melon plants (Mo et al., 2016). AMFs colonizationmediated strengthening of antioxidants defense systems was advocated to control ROS-metabolism and eventually alleviate oxidative stress in host plants under stress conditions (Peterson et al., 2004; Vos et al., 2013; Wu et al., 2014; Hashem et al., 2016). Involvement of ROS generation was also suggested in providing resistance in soybean against nematode (Meloidogyne javanica) infection (Beneventi et al., 2013). In mycorrhizal tomato roots, reduction of infection caused by root-knot nematode (M. incognita) was linked with ROS 
metabolism (Vos et al., 2013). Enhanced activities of major antioxidant enzymes including SOD, CAT, POD, GR, and APX were argued to improve cadmium $(\mathrm{Cd})$-tolerance in tomato via AMF-mediated ROS-scavenging (Hashem et al., 2016). Table 1 summarizes representative studies highlighting plantAMF/AMF-like ( $P$. indica) interaction and its link with ROS metabolism in response to various biotic and abiotic stress conditions.

\section{LINK OF ROS SIGNALING WITH STRESS TOLERANCE DURING PLANT-ARBUSCULAR MYCORRHIZAL ASSOCIATION}

In order to adapt with various biotic and abiotic stresses, plants are endowed with a highly complicated and elaborated signaling cascade. In response to stress conditions, plants utilize ROS as one of the key signaling players which also activate other defense related signaling pathways (Baxter et al., 2014; Xu and Brosche, 2014; Sewelam et al., 2016). Transcriptome analysis of Glomus mosseae/Medicago sativa during herbicide (atrazine) stress revealed higher stress tolerance via increased expression of electron transport related genes, ROS-scavenging antioxidants such as thioredoxin, glutaredoxin, and GPX. Additionally, a higher degradation of atrazine was also observed in mycorrhizal (G. mosseae)-treated M. sativa plants (versus non-treated plants), further corroborated its link with stress mitigation (Song et al., 2016).

Increasing evidences revealed that ROS-generation is one of the most frequent responses triggered in plants that represent a general point for different signaling cascades under stress (Sewelam et al., 2016). ROS generation is also one of the characteristics of the early host-defense system during initial microbial invasion with host plants and can also lead to the hypersensitive reaction and cell death at the site of interaction (Puppo et al., 2013). However, detailed reports on ROS signature kinetics are still very limited during initial stages of microbial interaction with plant. A transient increase of ROS was observed

TABLE 1 | Representative studies highlighting AMF/P. indica mediated-stress tolerance associated with the metabolism of reactive oxygen species (ROS) in different plants.

\begin{tabular}{|c|c|c|c|c|c|}
\hline $\begin{array}{l}\text { Name of the interacting } \\
\text { fungi }\end{array}$ & Plant & Stress tolerance & $\begin{array}{l}\text { ROS metabolism in } \\
\text { colonized plants }\end{array}$ & $\begin{array}{l}\text { *Potential stress } \\
\text { tolerance-mechanism }\end{array}$ & Reference \\
\hline Glomus mosseae & $\begin{array}{l}\text { Solanum lycopersicum } \\
\text { (Tomato) }\end{array}$ & Cadmium (Cd) stress & $\begin{array}{l}\text { Increased level of SOD, } \\
\text { CAT, POD, GR, and } \\
\text { APX }\end{array}$ & $\begin{array}{l}\text { AMF-mediated ROS } \\
\text { scavenging }\end{array}$ & Hashem et al., 2016 \\
\hline G. mosseae & Medicago sativa (alfalfa) & $\begin{array}{l}\text { Atrazine (Herbicide) } \\
\text { stress }\end{array}$ & $\begin{array}{l}\text { High level of } \\
\text { thioredoxin, } \\
\text { glutaredoxin and GPX }\end{array}$ & $\begin{array}{l}\text { High GPX activity may } \\
\text { link with alleviation of } \\
\text { atrazine stress }\end{array}$ & Song et al., 2016 \\
\hline \multirow[t]{3}{*}{ Piriformospora indica } & $\begin{array}{l}\text { Hordeum vulgare } \\
\text { (Barley) }\end{array}$ & Salt stress & $\begin{array}{l}\text { High antioxidant } \\
\text { activities and } \\
\text { glutathione-ascorbate } \\
\text { cycle activation }\end{array}$ & $\begin{array}{l}\text { Stress tolerance link } \\
\text { with increase in } \\
\text { antioxidants }\end{array}$ & $\begin{array}{l}\text { Waller et al., 2005; } \\
\text { Baltruschat et al., } 2008\end{array}$ \\
\hline & & $\begin{array}{l}\text { Biotic stress (Fusarium } \\
\text { culmorum) }\end{array}$ & Increased antioxidants & $\begin{array}{l}\text { Stress tolerance link } \\
\text { with increase in ROS } \\
\text { metabolism }\end{array}$ & Waller et al., 2005 \\
\hline & Zea mays (Maize) & $\begin{array}{l}\text { Biotic stress (Fusarium } \\
\text { verticillioides) }\end{array}$ & $\begin{array}{l}\text { High antioxidant } \\
\text { enzymatic activities }\end{array}$ & $\begin{array}{l}\text { High antioxidants } \\
\text { proposed to link with } \\
\text { stress tolerance }\end{array}$ & Kumar et al., 2009 \\
\hline $\begin{array}{l}\text { P. indica and Azotobacter } \\
\text { chroococcum } \\
\text { (Co-inoculation) }\end{array}$ & $\begin{array}{l}\text { Triticum aestivum } \\
\text { (Wheat) }\end{array}$ & Zinc stress & $\begin{array}{l}\text { High APX and } \\
\text { peroxidase activity }\end{array}$ & $\begin{array}{l}\text { Induced antioxidant } \\
\text { activities }\end{array}$ & $\begin{array}{l}\text { Abadi and Sepehri, } \\
2016\end{array}$ \\
\hline $\begin{array}{l}\text { Rhizophagus manihotis and } \\
\text { Funneliformis mosseae }\end{array}$ & Olea europaea (Olive) & Drought stress & $\begin{array}{l}\text { Low } \mathrm{H}_{2} \mathrm{O}_{2} \text { in } \\
\text { AMF-colonized plants }\end{array}$ & $\begin{array}{l}\text { Low } \mathrm{H}_{2} \mathrm{O}_{2} \text { level } \\
\text { correlated with drought } \\
\text { tolerance }\end{array}$ & Fouad et al., 2014 \\
\hline $\begin{array}{l}\text { R. intraradices and F. } \\
\text { mosseae }\end{array}$ & $\begin{array}{l}\text { Phoenix dactylifera } \\
\text { (Date Palm) }\end{array}$ & Drought stress & $\begin{array}{l}\text { High antioxidant- } \\
\text { enzymatic activities }\end{array}$ & $\begin{array}{l}\text { Antioxidant defense } \\
\text { system alleviates long } \\
\text { term drought stress. }\end{array}$ & Benhiba et al., 2015 \\
\hline Glomus sps. & $\begin{array}{l}\text { Citrus reticulate } \\
\text { (Mandarin orange) }\end{array}$ & Drought stress & $\begin{array}{l}\text { High antioxidant- } \\
\text { enzymatic activities }\end{array}$ & $\begin{array}{l}\text { Increased antioxidant } \\
\text { defense system link } \\
\text { with oxidative stress } \\
\text { tolerance }\end{array}$ & Sarkar et al., 2016 \\
\hline G. mosseae & $\begin{array}{l}\text { S. lycopersicum } \\
\text { (Tomato) }\end{array}$ & $\begin{array}{l}\text { biotic stress } \\
\text { (Meloidogyne incognita) }\end{array}$ & $\begin{array}{l}\text { Reduction of root-knot } \\
\text { nematode infection }\end{array}$ & $\begin{array}{l}\text { Involvement of ROS } \\
\text { metabolism with } \\
\text { reduction of the } \\
\text { nematode infection }\end{array}$ & Vos et al., 2013 \\
\hline
\end{tabular}

*ROS may be one of the associated mechanisms or it may likely to have link with stress tolerance. 


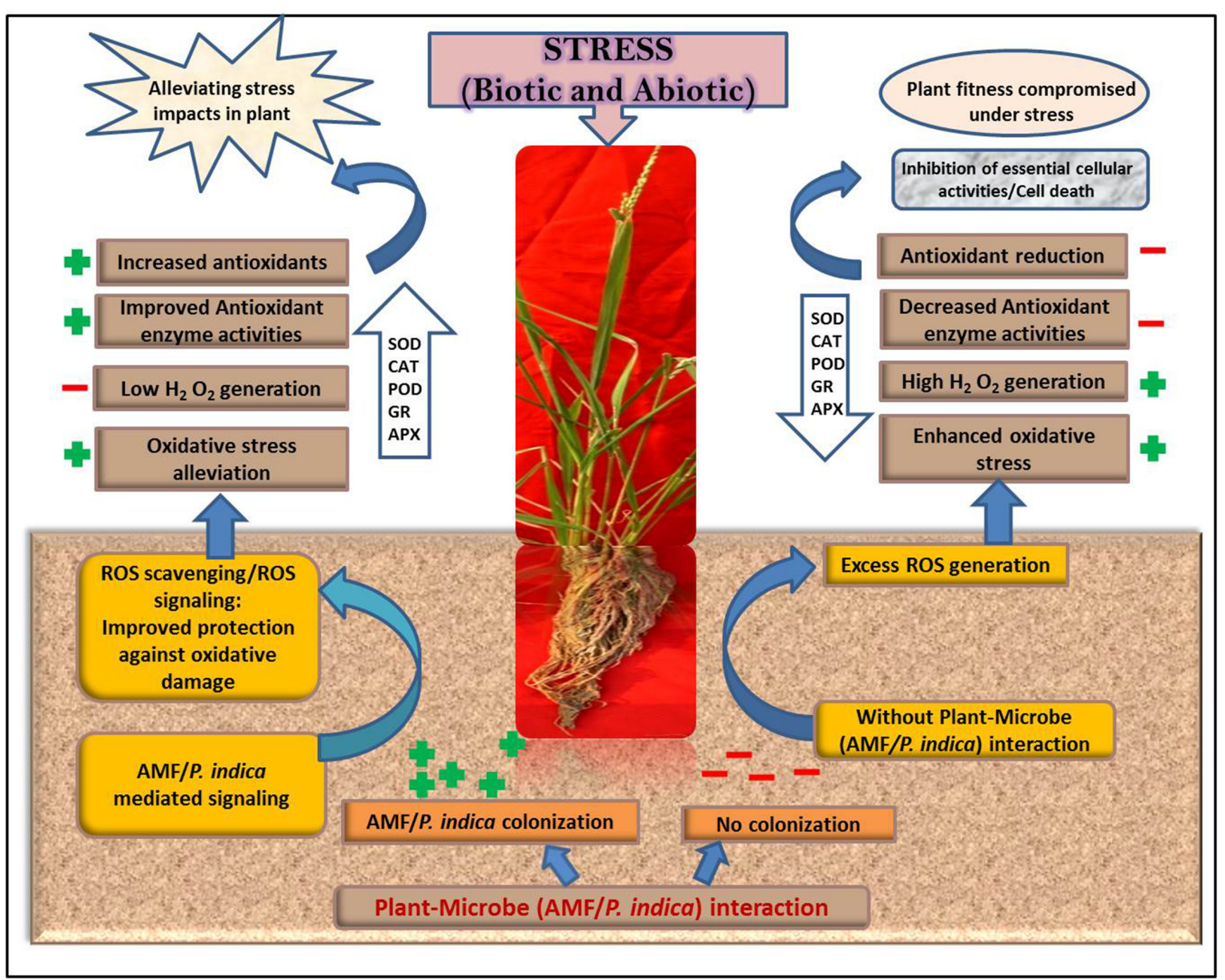

FIGURE 1 | Schematic representation of reactive oxygen species (ROS) generation and signaling during plant- arbuscular mycorrhizal fungi (AMF)/Piriformospora indica interaction in response to stress. The left panel of the figure indicates the ROS generation and signaling in presence of AMF/P. indica interaction, while the right panel demonstrates high ROS in absence of mycorrhizal interaction. AMF/P. indica colonization in plant roots can help the plant to cop the detrimental effect of stress, directly or indirectly, on plant functionality and metabolism. Altered ROS signaling/metabolism, in response to biotic and abiotic stress, link with stress tolerance in mycorrhizal colonized plants consequently provides stress tolerance; while, the scenario is just reverse in case of non-colonized plants i.e., high ROS production followed by the inhibition of plant cellular activities thus affecting the plant fitness. AMF/P. indica colonized plants were able to withstand stress induced damage by increasing the production of various antioxidant compounds, which helps to scavenge ROS and thus in turn enhance the activities of various antioxidant enzymes as listed inside the arrow. The positive (+) and negative (-) sign in figure denotes an increased and decreased levels, respectively. Superoxide dismutase (SOD), Catalase (CAT). Peroxidase (POD), Glutathione reductase (GR), and Ascorbate peroxidase (APX).

within seconds in root hairs of Phaseolus vulgaris after treatment with Nod factors (NFs), where specific role of ROS response during symbiotic association was proposed (Cardenas and Quinto, 2008). Moreover, among ROS, $\mathrm{H}_{2} \mathrm{O}_{2}$ is membranepermeable and plays an important role in signaling cascade as well as in defense response under stressful environments (Xia et al., 2009; Saxena et al., 2016). Thus, $\mathrm{H}_{2} \mathrm{O}_{2}$ has emerged as an active signaling player which is also involved in regulation of specific biological reactions/cellular metabolism and stress tolerance (Neill et al., 2002; Yan et al., 2007; Saxena et al., 2016). In M. truncatula-Sinorhizobium meliloti, exogenously supplied $\mathrm{H}_{2} \mathrm{O}_{2}$ was associated with induced $M t S p k 1$ gene (encoding a putative protein kinase) and also its conformed functional role was argued in the control of genes linked to rhizobia symbiosis (Andrio et al., 2013).

\section{ROS MODULATION DURING INTERACTION OF PLANTS AND P. indica UNDER STRESS CONDITION}

Piriformospora indica mediated stress tolerance has been credibly reported in various crops including barley (Waller et al., 2005; Deshmukh and Kogel, 2007), wheat (Serfling et al., 2007), maize (Kumar et al., 2009), tomato (Sarma et al., 2011), and lentil (Dolatabadi et al., 2012). In rhizosphere, P. indica was reported to enhance the levels of alkaline phosphatase and acid phosphatase enzymes that in turn contributes for higher phosphate uptake in plants (Das et al., 2014). However, information is still meager on the relation of $P$. indica with the status of ROS in plants with mycorrhizal association. Nevertheless, the control of 
ROS generation and the modulation of major components of antioxidant defense pathway were argued as a key mechanism underlying $P$. indica mediated improved stress tolerance in wheat, barley and maize (Waller et al., 2005; Serfling et al., 2007; Kumar et al., 2009). In plant roots, ROS generation and activation of defense related responses was reported during initial mycorrhizal associations (Pozo and Azcón-Aguilar, 2007). Notably, the generation of ROS was initially observed before physical contact of $P$. indica with plant roots and no $\mathrm{H}_{2} \mathrm{O}_{2}$ was reported after establishment of symbiotic relationship between P. indica and plant root (Vadassery et al., 2009a; Camehl et al., 2011; Vahabi et al., 2015).

$\mathrm{H}_{2} \mathrm{O}_{2}$ was found to induce OXI1 (Oxidative Signal Inducible1) gene which consequently triggers defense response during pathogen infection (Rentel et al., 2004; Anthony et al., 2006; Petersen et al., 2009). In Arabidopsis roots, OXI1 (a serine/threonine kinase) was shown to be required for oxidative burst/ROS-mediated responses including root hair elongation and disease tolerance against biotrophic pathogens (Rentel et al., 2004; Petersen et al., 2009). Though, under favorable co-cultivation conditions, $\mathrm{H}_{2} \mathrm{O}_{2}$ generation was repressed in $P$. indica-colonized Arabidopsis roots while stimulation of growth response via $P$. indica involved PLD-PDK1-OXI1 cascade in Arabidopsis (Camehl et al., 2011). Activation of the GSHAsA cycle followed by increased antioxidant capacity was reported in P. indica colonized barley root (Waller et al., 2005). $P$. indica-mediated enhancement of antioxidants was reported to link with salt stress tolerance in the colonized barley plants (Baltruschat et al., 2008). Microbe derived effectors delivered during plant-mycorrhizal association can enhance the microbial infections and also manipulate the host metabolism. Recently, a study demonstrated that the expression of candidate effector (PIIN_08944) of P. indica was found to decrease the ROS burst activated by flg22 and chitin in barley (Akum et al., 2015). Coinoculation of $P$. indica and Azotobacter chroococcum in wheat enhanced APX and peroxidase-antioxidant enzyme activities under zinc-deprived environment (Abadi and Sepehri, 2016).

Recently, the exudates released via $P$. indica interaction were reported to initially lead to ROS generation, accumulation of stress-responsive phytohormone, stomatal closure and induce the defense responsive genes in root and/or shoot of Arabidopsis. Moreover, after the establishment of physical contact of plant with $P$. indica, defense responsive genes expression/number, phytohormone and ROS levels turned down; whereas, the stomata re-opened (Vahabi et al., 2015). Figure 1 schematically

\section{REFERENCES}

Abadi, V. A. J. M., and Sepehri, M. (2016). Effect of Piriformospora indica and Azotobacter chroococcum on mitigation of zinc deficiency stress in wheat (Triticum aestivum L.). Symbiosis 69, 9-19. doi: 10.1007/s13199-015-0361-z

Akum, F. N., Steinbrenner, J., Biedenkopf, D., Imani, J., and Kogel, K. (2015). The Piriformospora indica effector PIIN_08944 promotes the mutualistic sebacinalean symbiosis. Front. Plant Sci. 6:906. doi: 10.3389/fpls.2015.00906

Andrio, E., Marino, D., Marmeys, A., de Segonzac, M. D., and Damiani, I. (2013). Hydrogen peroxide-regulated genes in the $M$. truncatula-Sinorhizobium meliloti symbiosis. New Phytol. 198, 190-202. doi: 10.1111/nph.12120 highlights the link of ROS generation, scavenging and signaling with plant-mycorrhizal association and their cumulative effect on the enhanced plant fitness under stress.

\section{CONCLUSIONS AND PERSPECTIVES}

Symbiotic microbial association can enhance the ROSantioxidant defense system and ultimately improve the plant fitness under stress. Further, in future, exploration of ROS signatures kinetics during initial plant-arbuscular mycorrhizal association can enhance the basic understanding of mycorrhizal link with ROS generation. Additionally, molecular insights into the detailed kinetics of ROS metabolism in plant-mycorrhizal especially $P$. indica signaling are advocated to design innovative strategies via modulating the ROS metabolism and ultimately will help to improve plant productivity under stress conditions.

\section{AUTHOR CONTRIBUTIONS}

MN and NT developed the idea and wrote/finalized the MS. DB, RP, SG, and NA made the figures and developed table and helped in writing. All authors read and approved the final manuscript.

\section{FUNDING}

NT acknowledges partial support from Indo-French Centre for the Promotion of Advanced Research (IFCPAR/CEFIPRA; Proposal No. 4609-A).

\section{ACKNOWLEDGMENTS}

MN is thankful for partial financial support from the Department of Science and Technology (Grant-ECR/2016/000653), Govt. of India. SSG also acknowledges partial support from DST, Council of Scientific \& Industrial Research (CSIR) and University Grants Commission (UGC). NAA (SFRH/BPD/84671/2012) gratefully acknowledges the partial financial supports received from FCT (Government of Portugal) through contract, the Aveiro University Research Institute/CESAM (UID/AMB/50017/2013), and "COMPETE" through Project n. ${ }^{\circ}$ FCOMP-01-0124-FEDER02800 (FCT PTDC/AGR-PRO/4091/2012).
Anthony, R. G., Khan, S., Costa, J., Pais, M. S., and Bogre, L. (2006). The Arabidopsis protein kinase PTI1-2 is activated by convergent phosphatidic acid and oxidative stress signaling pathways downstream of PDK1 and OXI1. J. Biol. Chem. 281, 37536-37546. doi: 10.1074/jbc.M607341200

Apel, K., and Hirt, H. (2004). Reactive oxygen species: metabolism, oxidative stress, and signal transduction. Annu. Rev. Plant Biol. 55, 373-399. doi: 10.1146/annurev.arplant.55.031903.141701

Bakshi, M., Sherameti, I., Johri, A. K., Varma, A., and Oelmuller, R. (2014). Phosphate availability affects root architecture and development, plant performance and is controlled by root-colonizing microbes. J. Endocytobiosis Cell Res. 25, 56-65. 
Baltruschat, H., Fodor, J., Harrach, B. D., Niemczyk, E., Barna, B., Gullner, G., et al. (2008). Salt tolerance of barley induced by the root endophyte Piriformospora indica is associated with a strong increase in antioxidants. New Phytol. 180, 501-510. doi: 10.1111/j.1469-8137.2008.02583.x

Barna, B., Fodor, J., Harrach, B. D., Pogany, M., and Kiraly, Z. (2012). The Janus face of reactive oxygen species in resistance and susceptibility of plants to necrotrophic and biotrophic pathogens. Plant Physiol. Biochem. 59, 37-43. doi: 10.1016/j.plaphy.2012.01.014

Baxter, A., Mittler, R., and Suzuki, N. (2014). ROS as key players in plant stress signalling. J. Exp. Bot. 65, 1229-1240. doi: 10.1093/jxb/ert375

Beneventi, M. A., da Silva, O. B., de Sa, M. E. L., Firmino, A. A. P., de Amorim, R. M. S., Albuquerque, E. V. S., et al. (2013). Transcription profile of soybeanroot-knot nematode interaction reveals a key role of phythormones in the resistance reaction. BMC Genomics 10:322. doi: 10.1186/1471-2164-14-322

Benhiba, L., Fouad, M. O., Essahibi, A., Ghoulam, C., and Qaddoury, A. (2015). Arbuscular mycorrhizal symbiosis enhanced growth and antioxidant metabolism in date palm subjected to long-term drought. Trees 29, 1725-1733. doi: 10.1007/s00468-015-1253-9

Bose, J., Rodrigo-Moreno, A., and Shabala, S. (2014). ROS homeostasis in halophytes in the context of salinity stress tolerance. J. Exp. Bot. 65, 1241-1257. doi: $10.1093 / \mathrm{jxb} / \mathrm{ert} 430$

Camehl, I., Drzewiecki, C., Vadassery, J., Shahollari, B., Sherameti, I., Forzani, C., et al. (2011). The OXI1 kinase pathway mediates Piriformospora indicainduced growth promotion in Arabidopsis. PLoS Pathog. 7:e1002051. doi: 10.1371/journal.ppat.1002051

Cardenas, L., and Quinto, C. (2008). Reactive oxygen species (ROS) as early signals in root hair cells responding to rhizobial nodulation factors. Plant Signal. Behav. 3, 1-3. doi: 10.4161/psb.3.12.7004

Cruz, C., Fegghi, Z., Martins-Loucao, M. A., and Varma, A. (2013). "Plant nitrogen use efficiency may be improved through symbiosis with Piriformospora indica," in Piriformospora indica, Soil Biology, Vol. 33, eds A. Varma, G. Kost, and R. Oelmüller (Berlin: Springer-Verlag), 285-293.

Das, J., Ramesh, K. V., Maithri, U., Mutangana, D., and Suresh, C. K. (2014). Response of aerobic rice to Piriformospora indica. Indian J. Exp. Biol. 52, 237-251.

Deshmukh, S. D., and Kogel, K. H. (2007). Piriformospora indica protects barley from root rot caused by Fusarium graminearum. J. Plant Dis. Protect. 114, 263-268. doi: 10.1007/BF03356227

Dolatabadi, H. K., Goltapeh, E. M., Mohammadi, N., Rabiey, M., Rohani, N., and Varma, A. (2012). Biocontrol potential of root endophytic fungi and Trichoderma species against Fusarium wilt of lentil under in vitro and greenhouse conditions. J. Agric. Sci. Technol. 14, 407-420.

Doty, S. L. (2016). Plant-microbe symbiotic interactions. Plant Mol. Biol. 90:535. doi: 10.1007/s11103-016-0470-y

Espinosa, F., Garrido, I., Ortega, A., Casimiro, I., and Alvarez-Tinaut, M. C. (2014). Redox activities and ros, no and phenylpropanoids production by axenically cultured intact olive seedling roots after interaction with a mycorrhizal or a pathogenic fungus. PLoS ONE 9:e100132. doi: 10.1371/journal.pone.0100132

Farrar, K., Bryant, D., and Cope-Selby, N. (2014). Understanding and engineering beneficial plant-microbe interactions: plant growth promotion in energy crops. Plant Biotechnol. J. 12, 1193-1206. doi: 10.1111/pbi.12279

Fester, T., and Hause, G. (2005). Accumulation of reactive oxygen species in arbuscular mycorrhizal roots. Mycorrhiza 15, 373-379. doi: 10.1007/s00572005-0363-4

Fouad, O. M., Essahibi, A., Benhiba, L., and Qaddoury, A. (2014). Effectiveness of arbuscular mycorrhizal fungi in the protection of olive plants against oxidative stress induced by drought. Spanish J. Agric. Res. 12, 763-771. doi: $10.5424 /$ sjar/2014123-4815

Gill, S. S., Gill, R., Trivedi, D. K., Anjum, N. A., Sharma, K. K., Ansari, M. W., et al. (2016). Piriformospora indica: potential and significance in plant stress tolerance. Front. Microbiol. 7:332. doi: 10.3389/fmicb.2016.00332

Gill, S. S., and Tuteja, N. (2010). Reactive oxygen species and antioxidant machinery in abiotic stress tolerance in crop plants. Plant Physiol. Biochem. 48, 909-930. doi: 10.1016/j.plaphy.2010.08.016

Goh, C., Vallejos, D. F. V., Nicotra, A. B., and Mathesius, U. (2013). The impact of beneficial plant-associated microbes on plant phenotypic plasticity. J. Chem. Ecol. 39, 826-839. doi: 10.1007/s10886-013-0326-8
Hashem, A., Abd Allah, E. F., Alqarawi, A. A., Al Huqail, A. A., Egamberdieva, D., and Wirth, S. (2016). Alleviation of cadmium stress in Solanum lycopersicum L. by arbuscular mycorrhizal fungi via induction of acquired systemic tolerance. Saudi J. Biol. Sci 23, 272-281. doi: 10.1016/j.sjbs.2015.11.002

Jajic, I., Sarna, T., and Strzalka, K. (2015). Senescence, stress, and reactive oxygen species. Plants 4, 393-411. doi: 10.3390/plants4030393

Jogawat, A., Saha, S., Bakshi, M., Dayaman, V., Kumar, M., Dua, M., et al. (2013). Piriformospora indica rescues growth diminution of rice seedlings during high salt stress. Plant Signal. Behav. 9:e26891. doi: 10.4161/psb.26891

Johnson, J. M., Alex, T., and Oelmüller, R. (2014). Piriformospora indica: the versatile and multifunctional root endophytic fungus for enhanced yield and tolerance to biotic and abiotic stress in crop plants. J. Tropical Agric. 52, 103-122.

Kadota, Y., Shirasu, K., and Zipfel, C. (2015). Regulation of the NADPH oxidase RBOHD during plant immunity. Plant Cell Physiol. 56, 1472-1480. doi: 10.1093/pcp/pcv063

Kiirika, L. M., Schmitz, U., and Colditz, F. (2014). The alternative Medicago truncatula defense proteome of ROS-defective transgenic roots during early microbial infection. Front. Plant Sci. 5:341. doi: 10.3389/fpls.2014.00341

Kumar, M., Yadav, V., Tuteja, N., and Johri, A. K. (2009). Antioxidant enzyme activities in maize plants colonized with Piriformospora indica. Microbiology 155, 780-790. doi: 10.1099/mic.0.019869-0

Mine, A., Sato, M., and Tsuda, K. (2014). Toward a systems understanding of plantmicrobe interactions. Front. Plant Sci. 5:423. doi: 10.3389/fpls.2014.00423

Mittler, R., Vanderauwera, S., Gollery, M., and Breusegem, F. V. (2004). Reactive oxygen gene network of plants. Trends Plant Sci. 9, 490-498. doi: 10.1016/j.tplants.2004.08.009

Mittler, R., Vanderauwera, S., Suzuki, N., Miller, G., Tognetti, V. B., Vandepoele, K., et al. (2011). ROS signaling: the new wave? Trends Plant Sci. 16, 300-309. doi: 10.1016/j.tplants.2011.03.007

Mo, Y., Wang, Y., Yang, R., Zheng, J., Liu, C., Li, H., et al. (2016). Regulation of plant growth, photosynthesis, antioxidation and osmosis by an arbuscular mycorrhizal fungus in watermelon seedlings under well-watered and drought conditions. Front. Plant Sci. 7:644. doi: 10.3389/fpls.2016.00644

Muthukumar, T., and Udaiyan, K. (2010). Growth response and nutrient utilization of Casuarina equisetifolia seedlings inoculated with bioinoculants under tropical nursery conditions. New For. 40, 101-118. doi: 10.1007/s11056-0099186-z

Nath, M., Yadav, S., Sahoo, R. K., Passrciha, N., Tuteja, R., and Tuteja, N. (2016). PDH45 transgenic rice maintain cell viability through lower accumulation of $\mathrm{Na}+$, ROS and calcium homeostasis in roots under salinity stress. J. Plant Physiol. 191, 1-11. doi: 10.1016/j.jplph.2015.11.008

Neill, S. J., Desikan, R., and Hancock, J. (2002). Hydrogen peroxide signaling. Curr. Opin. Plant Biol. 5, 388-395. doi: 10.1016/S1369-5266(02) 00282-0

Petersen, L. N., Ingle, R. A., Knight, M. R., and Denby, K. J. (2009). OXI1 protein kinase is required for plant immunity against Pseudomonas syringae in Arabidopsis. J. Exp. Bot. 60, 3727-3735. doi: 10.1093/jxb/erp219

Peterson, R. L., Massicotte, H. B., and Melville, L. H. (2004). Mycorrhizas: Anatomy and Cell Biology. London: CABI Publishing.

Porcel, R., Aroca, R., and Ruiz-Lozano, J. M. (2012). Salinity stress alleviation using arbuscular mycorrhizal fungi. A review. Agron. Sust. Dev. 32, 181-200. doi: 10.1007/s13593-011-0029-x

Pozo, M. J., and Azcón-Aguilar, C. (2007). Unraveling mycorrhiza-induced resistance. Curr. Opin. Plant Biol. 10, 393-398. doi: 10.1016/j.pbi.2007.05.004

Prasad, R., Kamal, S., Sharma, P. K., Oelmueller, R., and Varma, A. (2013). Root endophyte Piriformospora indica DSM 11827 alters plants morphology, enhances biomass and antioxidant activity of medicinal plant Bacopa monniera. J. Basic Microbiol. 53, 1016-1024. doi: 10.1002/jobm.201200367

Puppo, A., Pauly, N., Boscari, A., Mandon, K., and Brouquisse, R. (2013). Hydrogen peroxide and nitric oxide: key regulators of the legume Rhizobium and mycorrhizal symbioses. Antioxid. Redox Signal. 18, 2202-2219. doi: $10.1089 /$ ars.2012.5136

Rasool, S., Ahmad, A., Siddiqi, T. O., and Ahmad, P. (2013). Changes in growth, lipid peroxidation and some key antioxidant enzymes in chickpea genotypes under salt stress. Acta Physiol. Plant 35, 1039-1050. doi: 10.1007/s11738-012$1142-4$ 
Rentel, M. C., Lecourieux, D., Ouaked, F., Usher, S. L., Petersen, L., Okamoto, H., et al. (2004). OXI1 kinase is necessary for oxidative burst-mediated signalling in Arabidopsis. Nature 427, 858-861. doi: 10.1038/nature02353

Sanders, I. R. (2011). Mycorrhizal symbioses: how to be seen as a good fungus. Curr. Biol. 21, R550-R552. doi: 10.1016/j.cub.2011.06.022

Sarkar, J., Ray, A., Chakraborty, B., and Chakraborty, U. (2016). Antioxidative changes in Citrus reticulata L. induced by drought stress and its effect on root colonization by arbuscular mycorrhizal fungi. Eur. J. Biol. Res. 6, 1-13.

Sarma, M. V. R. K., Kumar, V., Saharan, K., Srivastava, R., Sharma, A. K., Prakash, A., et al. (2011). Application of inorganic carrier-based formulations of fluorescent pseudomonads and Piriformospora indica on tomato plants and evaluation of their efficacy. J. Appl. Microbiol. 111, 456-466. doi: 10.1111/j.13652672.2011.05062.x

Saxena, I., Srikanth, S., and Chen, Z. (2016). Cross talk between H2O2 and interacting signal molecules under plant stress response. Front. Plant Sci. 7:570. doi: $10.3389 /$ fpls.2016.00570

Schouteden, N., De Waele, D., Panis, B., and Vos, C. M. (2015). Arbuscular mycorrhizal fungi for the biocontrol of plant-parasitic nematodes: a review of the mechanisms involved. Front. Microbiol. 6:1280. doi: $10.3389 /$ fmicb. 2015.01280

Serfling, A., Wirsel, S. G. R., Lind, V., and Deising, H. B. (2007). Performance of the biocontrol fungus Piriformospora indica on wheat under greenhouse and field conditions. Phytopathology 97, 523-531. doi: 10.1094/PHYTO-97-4-0523

Sewelam, N., Kazan, K., and Schenk, P. M. (2016). Global plant stress signaling: reactive oxygen species at the cross-road. Front. Plant Sci. 7:187. doi: 10.3389/fpls.2016.00187

Sherameti, I., Tripathi, S., Varma, A., and Oelmuller, R. (2008). The root colonizing endophyte Pirifomospora indica confers drought tolerance in Arabidopsis by stimulating the expression of drought stress-related genes in leaves. Mol. Plant Microbe Interact. 21, 799-807. doi: 10.1094/MPMI-21-6-0799

Song, F., Li, J., Fan, X., Zhang, Q., Chang, W., Yang, F., et al. (2016). Transcriptome analysis of Glomus mosseae/Medicago sativa mycorrhiza on atrazine stress. Sci. Rep. 6:20245. doi: 10.1038/srep20245

Suzuki, N., Miller, G., Salazar, C., Mondal, H. A., Shulaev, E., Cortes, D. F., et al. (2013). Temporal-spatial interaction between ROS and ABA controls rapid systemic acclimation in plants. Plant Cell 25, 3553-3569. doi: 10.1105/tpc.113.114595

Tahat, M. M., and Sijam, K. (2012). Mycorrhizal fungi and abiotic environmental conditions relationship. Res. J. Environ. Sci. 6, 125-133. doi: 10.3923/rjes.2012.125.133

Tanaka, A., Christensen, M. J., Takemoto, D., Park, P., and Scott, B. (2006). Reactive oxygen species play a role in regulating a fungus-perennial ryegrass mutualistic interaction. Plant Cell 18, 1052-1066. doi: 10.1105/tpc.105.039263

Trivedi, D., Srivastava, A., Verma, P. K., Tuteja, N., and Gill, S. S. (2016). Piriformospora indica: a friend in need is a friend in deed. J. Bot. Sci. 5, 16-19.
Vadassery, J., Ranf, S., Drzewiecki, C., Mithöfer, A., Mazars, C., Scheel, D., et al. (2009a). A cell wall extract from Piriformospora indica promotes growth of Arabidopsis seedlings and induces intracellular calcium elevation in roots. Plant J. 59, 193-206. doi: 10.1111/j.1365-313X.2009.03867.x

Vadassery, J., Tripathi, S., Prasad, R., Varma, A., and Oelmüller, R. (2009b). Monodehydroascorbate reductase 2 and dehydroascorbate reductase 5 are crucial for a mutualistic interaction between Piriformospora indica and Arabidopsis. J. Plant Physiol. 166, 1263-1274. doi: 10.1016/j.jplph.2008.12.016

Vahabi, K., Sherameti, I., Bakshi, M., Mrozinska, A., Ludwig, A., Reichelt, M., et al. (2015). The interaction of Arabidopsis with Piriformospora indica shifts from initial transient stress induced by fungus-released chemical mediators to a mutualistic interaction after physical contact of the two symbionts. BMC Plant Biol. 15:58. doi: 10.1186/s12870-015-0419-3

Vos, C., Schouteden, N., van Tuinen, D., Chatagnier, O., Elsen, A., De Waele, D., et al. (2013). Mycorrhiza-induced resistance against the root-knot nematode Meloidogyne incognita involves priming of defense gene responses in tomato. Soil Biol. Biochem. 60, 45-54. doi: 10.1016/j.soilbio.2013.01.013

Waller, F., Achatz, B., Baltruschat, H., Fodor, J., Becker, K., Fischer, M., et al. (2005). The endophytic fungus Piriformospora indica reprograms barley to salt-stress tolerance, disease resistance, and higher yield. Proc. Natl. Acad. Sci. U.S.A. 102, 13386-13391. doi: 10.1073/pnas.0504423102

Wu, Q., Zou, Y., and Abd-Allah, E. F. (2014). "Mycorrhizal association and ROS in plants," in Oxidative Damage to Plants, ed. P. Ahmad (Cambridge, MA: Academic Press.), 453-475.

Xia, X. J., Wang, Y. J., Zhou, Y. H., Tao, Y., Mao, W. H., Shi, K., et al. (2009). Reactive oxygen species are involved in brassinosteroid-induced stress tolerance in cucumber. Plant Physiol. 150, 801-814. doi: 10.1104/pp.109.138230

$\mathrm{Xu}$, E., and Brosche, M. (2014). Salicylic acid signaling inhibits apoplastic reactive oxygen species signaling. BMC Plant Biol. 14:155. doi: 10.1186/1471-2229-14155

Yan, J., Tsuichihara, N., Etoh, T., and Iwai, S. (2007). Reactive oxygen species and nitric oxide are involved in ABA inhibition of stomatal opening. Plant Cell Environ. 30, 1320-1325. doi: 10.1111/j.1365-3040.2007.01711.x

Conflict of Interest Statement: The authors declare that the research was conducted in the absence of any commercial or financial relationships that could be construed as a potential conflict of interest.

Copyright (c) 2016 Nath, Bhatt, Prasad, Gill, Anjum and Tuteja. This is an openaccess article distributed under the terms of the Creative Commons Attribution License (CC BY). The use, distribution or reproduction in other forums is permitted, provided the original author(s) or licensor are credited and that the original publication in this journal is cited, in accordance with accepted academic practice. No use, distribution or reproduction is permitted which does not comply with these terms. 